\title{
Diet and resource partitioning among anurans in irrigated rice fields in Pantanal, Brazil
}

\author{
Piatti, L. ${ }^{a *}$ and Souza, FL. ${ }^{b *}$ \\ aPrograma de Pós-Graduação em Ecologia e Conservação, Universidade Federal de Mato Grosso do Sul - UFMS, \\ CEP 79070-900, Campo Grande, MS, Brazil \\ bDepartamento de Biologia, Centro de Ciências Biológicas e da Saúde, \\ Universidade Federal de Mato Grosso do Sul - UFMS, CEP 79070-900, Campo Grande, MS, Brazil \\ *e-mail: lilianapiatti@gmail.com; franco.souza@ufms.br \\ Received September 1, 2010 - Accepted October 28, 2010 - Distributed 31 August, 2011
}

(With 2 figures)

\begin{abstract}
Artificial ponds or irrigated systems scattered throughout farmlands can offer important habitats for anurans and can be interesting sites for research on species resources use in a changing landscape. This study describes the diet and resource partitioning among anurans inhabiting irrigated rice fields in the Pantanal region. Twenty categories of prey were found in the stomachs of Leptodactylus chaquensis, L. elenae, L. podicipinus and Rhinella bergi, the most frequent being Coleoptera, Hymenoptera, larvae of Hexapoda, Hemiptera, Diptera and Orthoptera. The great differences found in the diet of these species in rice fields compared to other locations, according to available records in the literature, was the increased importance of Hemipitera and Orthoptera and the decrease in importance of Hymenoptera in the diet of leptodactylids. These differences might be attributed to changes in the availability of resources in response to habitat modification. Although diet composition was very similar among species, niche overlap was larger than expected by chance, suggesting that the competition for food resources is not, or has not been, a significant force in determining the structure of this frog community. Two non-exclusive hypotheses could be considered as a justification for this result: 1) the high niche overlap could result from resource availability, which is sufficient to satisfy all species without any strong competition; 2) or the high values of niche overlap could be a selective force driving species to compete, but there has not been enough time to express a significant divergence in the species diet because the study area is characterised as a dynamic habitat influenced by frequent and cyclical changes.
\end{abstract}

Keywords: niche overlap, agroecosystems, Leptodactylidae, Bufonidae, diet.

\section{Dieta e partição de recursos entre anuros em campos de rizicultura no Pantanal, Brasil}

\section{Resumo}

Lagoas artificiais e sistemas irrigados em áreas de produção agrícola podem oferecer habitats importantes a anuros e ser significativos para investigações sobre o uso de recursos pelas espécies em ambientes modificados. Este estudo descreve a dieta e partição de recursos tróficos entre anuros de campos de rizicultura na região do Pantanal. Nos estômagos de Leptodactylus chaquensis, L. elenae, L. podicipinus e Rhinella bergi foram encontradas 20 categorias de presas, sendo Coleoptera, Hymenoptera, larvas de Hexápoda, Hemiptera, Diptera e Orthoptera as mais frequentes. Maiores diferenças encontradas na dieta dessas espécies em campos de arroz comparadas a de outros locais, de acordo com dados da literatura, foram o aumento da importância de Hemipitera e Orthoptera e a diminuição na importância de Hymenopteras na dieta dos leptodactilídeos. Essas diferenças talvez sejam reflexos de mudanças na disponibilidade de recursos de presas, em resposta às modificações ambientais. Apesar de as espécies apresentarem dietas bastante similares, a sobreposição de nicho foi maior que a esperada ao acaso, sugerindo que a competição por recursos alimentares não é, ou não tem sido, uma força significante na determinação na estrutura dessa comunidade de anuros. Duas respostas não exclusivas podem ser consideradas para justificar esse resultado: 1) a alta sobreposição de nicho poderia resultar da grande disponibilidade de recursos alimentares, a qual seria suficiente para satisfazer as necessidades de todas as espécies sem que haja forte competição; 2) ou os altos valores de sobreposição poderiam ser uma força seletiva que levasse as espécies à competição, mas que não têm tempo suficiente para se expressar em divergência na dieta das espécies pelo fato de a área de estudo ser um ambiente altamente dinâmico, sofrendo bruscas e cíclicas mudanças.

Palavras-chave: sobreposição de nicho, agroecossistemas, Leptodactylidae, Bufonidae, dieta. 


\section{Introduction}

Diet is an important life-history component of ecological niche. In communities, species feeding habits can play a key role in shaping competition dynamics (Lawlor, 1980) and predator-prey interactions (Richter-Boix et al., 2008). Particularly among anurans, community structure is often associated with a relationship between species habitat and diet (Duellman and Trueb, 1994).

Although some species can be considered specialists (Simon and Toft, 1991; Santos et al., 2003; Biavati et al., 2004), anurans are usually reported as exhibiting generalist and opportunistic feeding habits (Schaefer et al., 2006; Almeida-Gomes et al., 2007; Araújo et al., 2007; Mahan and Johnson, 2007) and, as a result of that, studies on feeding habits have reported a high niche overlap among syntopic and sympatric anuran species (Toft, 1981; Rosa et al., 2002; França et al., 2004; Almeida-Gomes et al., 2007). For generalist anurans, aspects such as phylogeny, foraging mode, prey availability and abundance, and morphological constraints for capture and ingestion of a given prey type can be related to resource partitioning among species (Lima, 1998; Lima and Magnusson, 1998; França et al., 2004; Santos et al., 2004). Furthermore, community niche differentiation can be influenced by human induced environmental changes, which may affect ecological interactions (Caldwell and Vitt, 1999; Albrech and Gotelli, 2001; Rocha et al., 2008).

Low anuran richness in the Pantanal is suggested to be related to the low habitat heterogeneity and high stress imposed on organisms by the striking differences between the rainy and dry seasons (Haddad and Prado, 2005; Prado et al., 2005; Uetanabaro et al., 2008). However, anuran abundance around the aquatic habitats scattered throughout the floodplain usually is high (Ponce and Nunes da Cunha, 1993; Uetanabaro et al., 2008).

In the last five decades, the original heterogeneous landscapes of Central Brazil, including the Pantanal areas, have been intensively modified and homogenised due to agricultural practices (Mato Grosso do Sul, 1989). The distinct ways of land use resulted in habitat changes at different spatial and temporal scales, which can lead to biodiversity loss (Piha, 2006). Nevertheless, humanmodified habitats, such as flooded rice fields, can still be highly diverse (Fujioka and Lane, 1997; Maeda, 2001; Elphick, 2004) providing important habitats for amphibian reproduction and population persistence (Baker and Halliday, 1999; Knutson et al., 2004), and, at the same time, providing opportunities to develop studies on species habitat use in changing landscape.

Although around 30 to 35 species are found in natural areas of Pantanal (Strüssmann et al., 2007) other studies carried out in disturbed areas found half this richness probably due to physical and chemical changes in these environments (Ávila and Ferreira, 2004; Piatti et al., 2010). Assuming that in environments homogenised in response to human changes, competition for resources can be another force that drives the community to a diversity decrease, this study describes the diet of some of the most abundant frog species inhabiting irrigated rice fields in the Pantanal and measures the similarity and overlap in the use of food resources between species.

\section{Materials and Methods}

The study was carried out from May 2007 to March 2008 in a farmland $\left(20^{\circ} 05^{\prime} 10^{\prime \prime} \mathrm{S}\right.$ and $\left.56^{\circ} 36^{\prime} 57^{\prime \prime} \mathrm{W}\right)$ destined primarily to irrigated rice production. This site (San Francisco Farm; municipality of Miranda, state of Mato Grosso do Sul, central Brazil) is located at the southeastern border of the Pantanal. The climate is Aw tropical hot and wet according to the Köppen classification (PCBAP, 1997), with a rainy season from October to March and a dry season from April to September. The natural flood regime lasts from January to April.

The rice plantations (since 1984) correspond to 3,400 ha out of a total area of 14,000 ha, with the remaining land comprising pastureland and native vegetation, including gallery and deciduous forest as well as distinct savanna-like (Cerrado) physiognomies. The rice plantations are divided into several 40 ha quadrats $(200 \times 2,000 \mathrm{~m})$ interconnected by vicinal roads and drainage channels. These drainage channels ( 2 to $10 \mathrm{~m}$ wide $\times 0.5$ to $1.5 \mathrm{~m}$ deep) are supplied by water from a nearby river (Miranda river), delivering water to the cultivated quadrats for $\sim 130$ days, according to the rice-growing season. Aquatic vegetation, herbaceous plants, and small trees grow along the banks of the drainage canals. A low richness ( 8 species) of frogs was recorded in these rice quadrats and these species are influenced by the spatial and temporal modifications resulting from agricultural practice as well as seasonal climatic factors such as temperature and rainfall (Piatti et al., 2010).

Anurans were hand-collected through nocturnal active search in five rice quadrats for five days every month. Since the aim of the study was to verify the use of rice plantation by species, quadrats close to or bordering some kind of vegetation in the area were avoided. So, only those quadrats surrounded by other quadrats were examined based on the assumption that the anurans could not cover long distances (over $2 \mathrm{~km}$ ) from forest patches or pastures to the sampled quadrats. Three $20 \times 20 \mathrm{~m}$ parcels were demarcated randomly in each sampled quadrat and checked for anurans between 7:30 PM and 11:00 PM. Sampling was carried out monthly, redistributing the three random parcels each sampling event. About one third of individuals found syntopically were captured to diet analyses, immediately anesthetised with xylocaine, fixed in 5\% formalin, and then transferred to $70 \%$ alcohol (IBAMA license register number: 13788-1). Specimens were deposited at the Coleção Zoológica de Referência at the Universidade Federal de Mato Grosso do Sul (ZUFMS, Campo Grande).

Stomach content was analysed and prey was quantified, measured, and identified at the Order level. Arachnida was divided into Aranae and Acari prey categories, while Coleoptera larvae and Lepidoptera larvae were classified 
as Hexapoda larvae. Prey volume was calculated by the ellipsoid formula (Equation 1)

$\mathrm{V}=\frac{4}{3} \pi\left(\frac{\mathrm{L}}{2}\right)\left(\frac{\mathrm{W}}{2}\right)^{2}$

where $L$ and $W$ are prey length and prey width, respectively. Variables were log-transformed and Spearman correlation was used to verify the relationship between maximum prey volume and anuran body length (snout-vent length) (Zar, 1999). Besides prey volume, food item analyses included frequency of occurrence (percentage of individual anurans in which a given food item was found) and the index of relative importance (IRI) of each prey category in each anuran species. IRI integrates both frequency of occurrence and volume (Equation 2)

$\mathrm{IRI}=(\mathrm{POt}) \times(\mathrm{PIt}+\mathrm{PVt})$

where POt is the frequency of occurrence of a given prey, and Pit and PVt is the number of preys (\%) and the prey volume in relation to total prey sampled, respectively (Pinka et al., 1971).

Relative importance indices of each prey were used to generate a Bray-Curtis similarity matrix between food and anuran species with posterior analysis by the hybrid multidimensional scaling ordination method (HMDS) using PATN software (Belbin, 1992).

The Pianka index $(a)$ was used to assess diet niche overlap among anuran species (Equation 3)

$$
\mathrm{a}=\frac{\sum \mathrm{U}_{1 \mathrm{j}} \times \sum \mathrm{U}_{2 \mathrm{j}}}{\sum\left(\mathrm{U}_{1 \mathrm{j}}\right)^{2} \times \sum\left(\mathrm{U}_{2 \mathrm{j}}\right)^{2}}
$$

where $\mathrm{U}_{1 \mathrm{j}}$ is the prey $j$ used by anuran species 1 and $\mathrm{U}_{2 \mathrm{j}}$ is the prey $j$ used by anuran species 2 (Pianka, 1973). To check for differences among observed and expected overlap index values, null models of "consumed resources community" were random generated with EcoSim (Gotelli and Entsminger, 2001). The original data matrix was randomised by 1,000 runs with the RA3 EcoSim algorithm option. RA3 is an intermediated model that sort out the original values, including zeros, inside each row (represented by each consumer or anuran species). Thus, original niche overlap is kept original (consumed prey richness) while food item importance is changed (Gotelli and Entsminger, 2001).

For both HMDS and niche overlap analyses, food items with a frequency of occurrence $<3.5 \%$ were considered rare and ignored. By proceeding this way, it was assumed that items with a low frequency of occurrence could have been accidentally ingested or were sporadically available to anuran species.

\section{Results}

Four anuran species (three Leptodactylidae and one Bufonidae) were symtopic during the sample and thus were analysed: Leptodactylus chaquensis Cei, $1950(\mathrm{~N}=121)$, L. podicipinus (Cope, 1862) $(\mathrm{N}=40)$, L. elenae Heyer,
1978 ( $\mathrm{N}=27$ ), and Rhinella bergi (Céspedez 2000, "1999") (N = 50). The number of individuals analysed for each species reflects the abundances found in rice fields. Seasonal variations of the anuran community in rice fields were described in Piatti et al. (2010).

Stomach content analyses revealed 20 prey items, including vertebrates and invertebrates (Table 1). Leptodactylus chaquensis exhibited the more diversified feeding habit (20 items) and was the only species to prey upon vertebrates (anurans and fishes). Leptodactylus podicipinus consumed 18 prey items, and R. bergi 10 items. The lowest diversity of food items consumed (nine) was verified for L. elenae. Highest IRI and frequency of occurrence were represented by Coleoptera, Hemiptera, Hymenoptera, Diptera, Orthoptera, and Hexapoda larvae (Table 1). A significant and positive relationship was verified between anuran species body size and ingested prey volume (Figure 1).

The HMDS ordination (stress $=0.194 ; \mathrm{r}=0.952$ ) (Figure 2) showed that L. chaquensis and L. podicipinus were the species with the more similar feeding habit. Individuals of these species shared eight food items, where Coleoptera, Hemiptera, and Hexapoda larvae were those with highest IRI. Leptodactylus elenae's diet differed from the other species because it was the only one with high IRI for Orthoptera. The greater number of prey categories consumed in significant proportions (frequency of occurrence $>3.5 \%$ ) and the equivalent IRI values in most food categories approached L. elenae to $L$. podicipinus in the ordination. The high values of IRI in the Hymenoptera category distanced $R$. bergi from the other species in the ordination. Similar IRI values in Coleoptera and Hemiptera categories and seven food items shared approached $R$. bergi to L. chaquensis.

Niche overlap analyses (Table 2) exhibited similar results with those from the ordination. The mean overlap niche index (0.499) was higher than the expected by chance $(0.233 ; \mathrm{p}=0.012)$.

\section{Discussion}

Diet of L. chaquensis individuals captured in irrigated rice fields was composed mainly of Coleoptera, Hemiptera, and Hexapoda larvae. These insect taxa also were considered important items in L. chaquensis diet for Argentinian populations (Schaefer et al., 2006), except for Hymenoptera which represented a lower IRI and frequency of occurrence for this rice field population.

Diet analyses of L. podicipinus from other Pantanal regions reported coleopterans, hymenopterans, and dipterans as the most frequent items consumed by this species (Rodrigues et al., 2004). As L. chaquensis, the differences in feeding habits verified for this L. podicipinus rice field population from those inhabiting other areas seem to result from the lower hymenopterans consumption. High Hymenoptera consumption by generalist anurans is usually explained as a consequence of this insect abundance in tropical regions (Borror and DeLong, 1988), although 
Table1. Frequency of occurrence and the index of relative importance - IRI (brackets values) of prey categories in Leptodactylus chaquensis $(\mathrm{n}=121)$, L. elenae $(\mathrm{n}=27)$, L. podicipinus $(\mathrm{n}=40)$ and Rhinella bergi $(\mathrm{n}=50)$ colleted in rice fields on San Francisco Farm, Miranda, MS, Brazil.

\begin{tabular}{lcccc}
\hline \multicolumn{1}{c}{ Prey } & \multicolumn{4}{c}{ Anuran species } \\
\cline { 2 - 5 } \multicolumn{1}{c}{ category } & L. chaquensis & L. elenae & L. podicipinus & R. bergi \\
\hline Blattaria & $0.83(0)$ & $11.11(166.24)$ & $2.5(0)$ & $0(0)$ \\
Coleoptera & $57.85(\mathbf{3 8 4 2 . 4 4})$ & $25.93(613.69)$ & $47.5(\mathbf{2 0 0 6 . 5 5})$ & $82(5195.78)$ \\
Collembola & $2.48(0)$ & $0(0)$ & $0(0)$ & $2(0)$ \\
Diptera & $17.35(25.94)$ & $11.11(63.23)$ & $30(249.79)$ & $26(93.14)$ \\
Hemiptera & $42.15(3297.15)$ & $14.81(394.22)$ & $27.5(1107.66)$ & $20(1440.39)$ \\
Homoptera & $21.49(148)$ & $3.7(12.06)$ & $22.5(388.08)$ & $4(1.18)$ \\
Hymenoptera & $23.14(18.15)$ & $14.81(179.04)$ & $20(183.39)$ & $92(\mathbf{6 2 6 5 . 0 9})$ \\
Isoptera & $1.65(0)$ & $0(0)$ & $2.5(0)$ & $12(37.67)$ \\
Hexapoda larvae & $32.23(640.74)$ & $25.83(769.89)$ & $27.5(874.96)$ & $16(78.08)$ \\
Lepidoptera & $2.48(0)$ & $0(0)$ & $0(0)$ & $0(0)$ \\
Odonata & $2.48(0)$ & $0(0)$ & $5(21.39)$ & $0(0)$ \\
Orthoptera & $19.83(40.90)$ & $40.74(\mathbf{2 8 5 0 . 8 6})$ & $10(115.19)$ & $6(3.34)$ \\
Psocoptera & $0.83(0)$ & $0(0)$ & $0(0)$ & $0(0)$ \\
Acari & $2.48(0)$ & $0(0)$ & $2.5(0)$ & $0(0)$ \\
Araneae & $21.49(17.22)$ & $18.51(260.24)$ & $15(139.2)$ & $18(16.93)$ \\
Crustacea & $1.66(0)$ & $0(0)$ & $0(0)$ & $0(0)$ \\
Diplopoda & $0.83(0)$ & $0(0)$ & $0(0)$ & $0(0)$ \\
Mollusca & $3.31(0)$ & $0(0)$ & $5(24.51)$ & $0(0)$ \\
Anura & $2.48(0)$ & $0(0)$ & $0(0)$ & $0(0)$ \\
Characiforme & $0.83(0)$ & $0(0)$ & $0(0)$ & $0(0)$ \\
\hline Bold vatura & & & \\
\end{tabular}

Bold values are the greatest IRI for each anuran species.

Table 2. Trophic niche overlap values, calculed by Pianka's index, between Leptodactylus chaquensis, L. elenae, L. podicipinus and Rhinella bergi colleted in rice fields of San Francisco Farm, Miranda, MS, Brazil.

\begin{tabular}{lcccc}
\hline & L. chaquensis & L. elenae & L. podicipinus & R. bergi \\
\hline L. chaquensis & - & & & \\
L. elenae & 0.274 & - & & \\
L. podicipinus & 0.935 & 0.359 & 0.639 & - \\
R. bergi & 0.589 & 0.196 & & \\
\hline
\end{tabular}

Toft (1981) and Strüssmann et al. (1984) suggest that ant capture rates by Leptodactylidae frogs is low when compared with prey availability in the habitat. Thus, lower importance of Hymenoptera in association with a higher Hemiptera consumption detected for both $L$. chaquensis and $L$. podicipinus from the irrigated rice fields might be attributed to changes in arthropod community due to local habitat alteration as a consequence of agricultural practices. While in homogeneous habitats, ant richness and abundance is low (Vargas et al., 2007), most hemipterans found in the anuran stomachs in the present study were identified as Oebalus poecila (Dalla, 1851) and Tibraca limbativentris (Stal, 1860), two important pest species in rice farming (Ferreira et al., 2001).
While Orthoptera was the major prey type verified for L. elenae captured in the rice fields, populations from the Cerrado (Araújo et al., 2007) and Amazonian Forest (Caldwell and Vitt, 1999) exhibited a diet composed mainly of Coleoptera and Hemiptera. This difference in population diet composition can reflect habitat prey availability, since high orthoperan abundance is associated to less complex habitats, such as open areas (Borror and DeLong, 1988).

Leptodactylidae frogs are non-selective predators, usually exhibiting a generalist feeding habit, and consuming prey according to their body size and gape (Araújo et al., 2007). Among them species of the present study, L. chaquensis was the largest one and also had a more diversified diet, including large prey like fishes, anurans and Lepidoptera. Leptodactylus podicipinus exhibited a feeding habit similar 

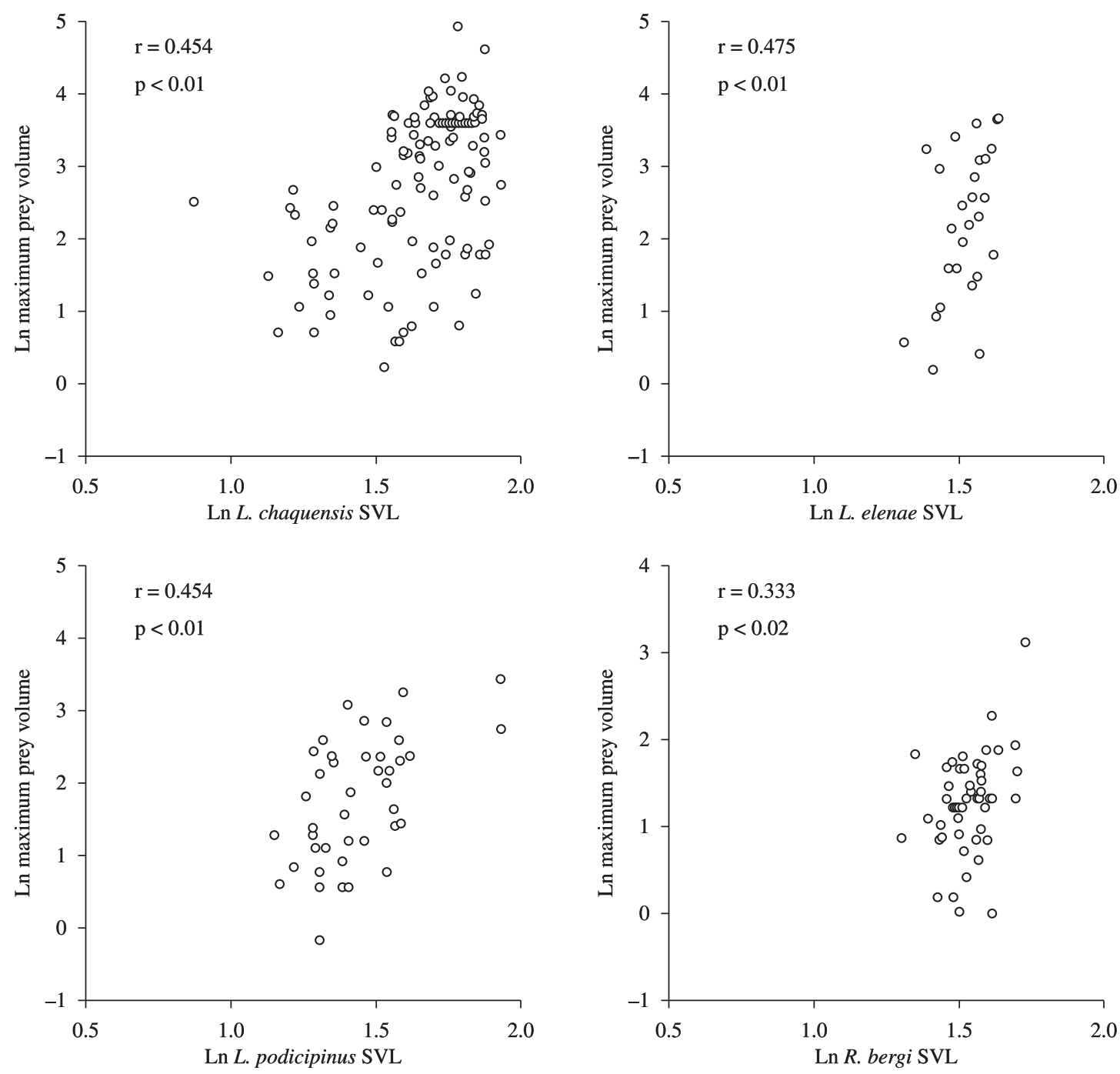

Figure 1. Relationship between snout-vent length (SVL) and maximum prey volume found in L. chaquensis, L. elenae, $L$. podicipinus and $R$. bergi stomachs in rice field of San Francisco Farm, Miranda, MS, Brazil. $r=$ Spearman Coefficient values; $\mathrm{p}=$ significance test values.

to L. chaquensis. The close phylogenetic relationship among these species (Ponssa, 2008) could reflect a similar foraging mode and habitat occupancy, resulting in a high niche overlap among them. In contrast, IRI and frequency of occurrence of smaller prey types, such as Diptera, were assigned mainly to $L$. podicipinus, suggesting that differences in feeding habits among $L$. podicipinus and $L$. chaquensis can be related to their distinct body sizes. The lower richness of food items found in stomach contents of L. elenae could be attributed to the small sample size. However, higher IRI and frequency of occurrence of Orthoptera suggest that this species may exhibit a distinct feeding habit.

Although the above hypothesis on lower ant abundance could be addressed to explain the feeding habits of Leptodactylus spp. in the rice fields, the importance of
Hymenoptera in the diet of $R$. bergi was evident. No attempt was made to quantify the importance values for Hymenoptera families, but Formicinae was the dominant item in the species' stomach contents. Bufonidae frogs can be classified as ant-specialist predators (Toft, 1981; Flowers and Graves, 1995; Hirai and Matsui, 2001; Isacch and Barg, 2002; Rosa et al., 2002) and studies on $R$. granulosa diet from northeastern Brazil suggest this tendency (Damasceno, 2005). Even though irrigated rice fields could have affected ant abundance, the high consumption of these insects by $R$. bergi indicates a feasible specialist feeding habit in this anuran species.

High niche overlap is usually reported for sympatric and syntopic anuran species, which is generally explained by the high prey availability and different foraging habits (Toft, 1981; Rosa et al., 2002; França et al., 2004; Almeida- 


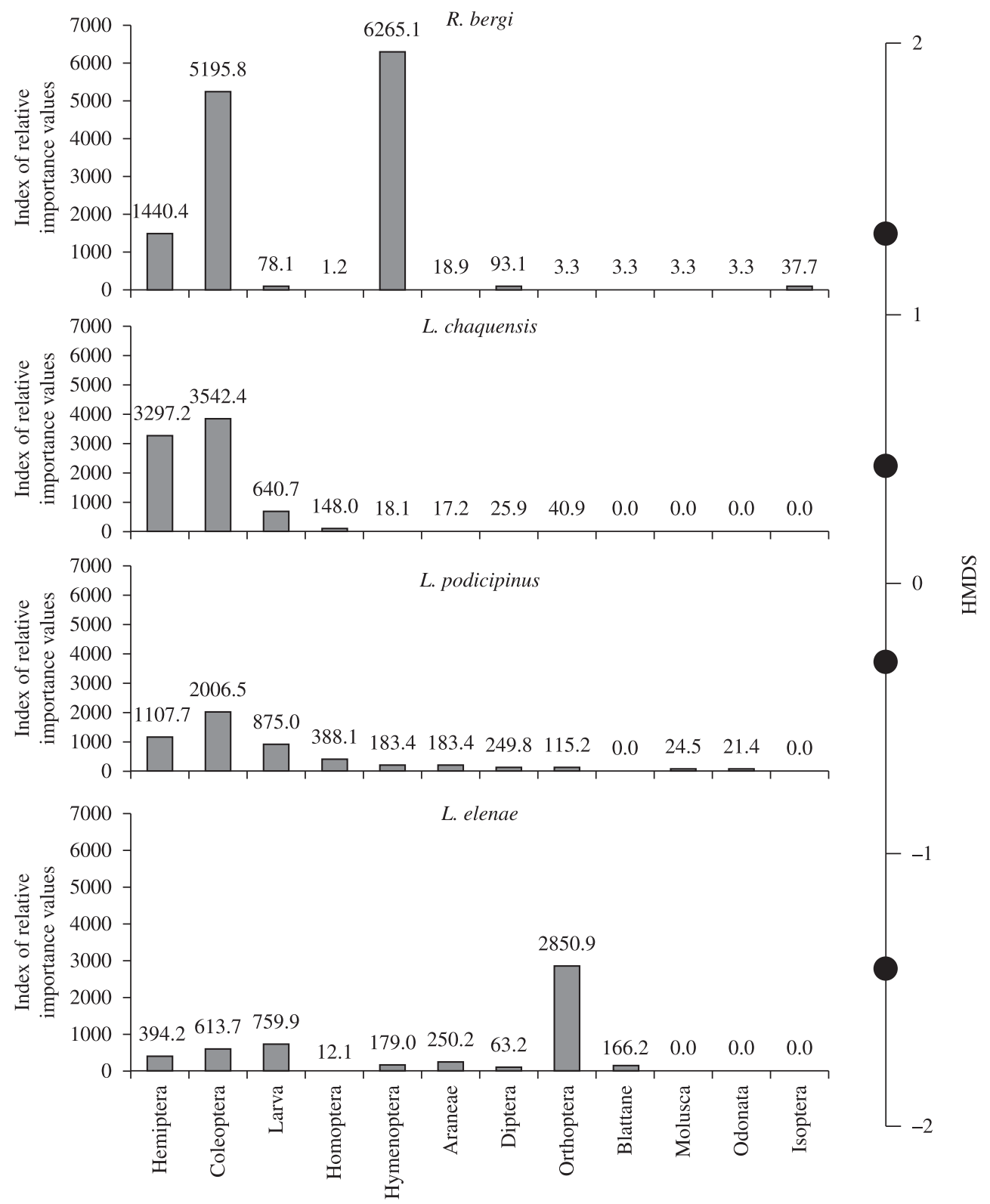

Figure 2. Index of relative importance - IRI (Pinkas et al., 1971) of items consumed to Leptodactylus chaquensis, L. elenae, L. podicipinus and Rhinella bergi and ordination in one dimension (HMDS, stress $=0,194, \mathrm{r}^{2}=0,952$ ) of anuran species regarding individual's diets.

Gomes et al., 2007). In the present study, niche overlap among the four anuran species according to a randomised data matrix was higher than that expected by chance. This result suggests that food competition is not so strong to shape this anuran community. Two traditional interpretations are frequently addressed for this resource partitioning pattern. First, a high niche overlap results from enough resource availability in the habitat to satisfy the species (Albrech and Gotelli, 2001) and second, the high values of niche overlap could be a selective force driving species to compete, but there has not been enough time to express a significant divergence in the species diet (Sale, 1974; Connel, 1980). Both non exclusive hypotheses could explain our results.

Given the landscape modification resulting in a homogeneous habitat characterised by rice fields, local anuran prey diversity could have been severely affected (Corrêa et al., 2006). Feeding habits of the four anuran species revealed that some prey are abundant in the rice fields (hemipterans, lepidopterans larvae, and coleopterans) that could compensate the apparent low prey diversity in the area, thus providing sufficient resources for the frog community. Also, anuran richness in the rice fields is lower 
than in neighbouring areas (Piatti et al., 2010). Species can be exploiting the habitat in distinct ways, including foraging modes and activity time, leading to coexistence and resource partitioning, which minimises niche overlap (Cunha and Vieira, 2004). Additionally, although most studies on food usually identify prey at order level, the use of such broad food categories in the analysis could mask resource partitioning results, suggesting that efforts in prey identification at lower levels including families, genera or species must be emphasised.

Regarding the non detection of competition related to the short time for its expression as diet divergence and consequent niche divergence, Hutchinson (1961) suggested that the result in a competitive interaction can be less important if the habitat is subject to constant changes. While at an initial point in time, competitive exclusion could be expressed among species in a habitat with low resource availability, the dynamics of such changing habitat could propitiate species coexistence in a subsequent point in time. During rice field flooding, species could have abundant feeding resources (low competition), but as the crop ends, food becomes scarce (high competition). Considering that the study area is characterised as a dynamic habitat influenced by frequent and cyclical changes in both physical (irrigated and non-irrigated periods, resting soil and harvesting periods) and chemical (use of pesticides) structures, competition by the anuran species in artificial wetlands might be a time-scaled phenomenon. However, only through research that assesses the availability of food resources for the anurans, taking into consideration their temporal changes, could this hypothesis be confirmed or refuted completely.

Acknowledgements - The authors are grateful to the Universidade Federal de Mato Grosso do Sul and the Conselho Nacional de Desenvolvimento Científico e Tecnológico (Process $n^{\circ} 470148 / 2006-3$ ) for financial support, to Fazenda San Francisco for logistical support, and to Ibama for permission to capture anurans (Process $\mathrm{n}^{\circ}$ 13788-1). Thanks are extended to P. Landgref Filho, C. Aoki, F. Maragno and F.I. Martins who helped with field trips and lab work, and C.P.A. Prado, R.A. Brandão, C. Strüssmann, V.L. Ferreira and A.P. Lima who made valuable suggestions on the early version of the manuscript. F.L. Souza receives a research grant from the Conselho Nacional de Desenvolvimento Científico e Tecnológico, CNPq (306034/2008-5).

\section{References}

ALBRECH, M. and GOTELLI, NJ., 2001. Spatial and temporal niche partitioning in grassland ants. Oecologia, no. 126, p. 134141. http://dx.doi.org/10.1007/s004420000494

ALMEIDA-GOMES, M., HATANO, FH., SLUYS, MV. and ROCHA, CFD., 2007. Diet and microhabitat use by two Hylodinae species (Anura, Cycloramphidae) living in sympatry and syntopy in a Brazilian Atlantic Rainforest area. Iheringia Série Zoologia, no. 97, p. 27-30. http://dx.doi.org/10.1590/S0073-47212007000100005

ARAÚJO, MS., REIS, SF., GIARETTA, AA., MACHADO, G. and BOLNICK, D., 2007. Intrapopulation diet variation in four frogs (Leptodactylidae) of the Brazilian Savanna. Copeia, no. 2007 , p. $855-865$.

ÁVILA, RW. and FERREIRA, VL., 2004. Riqueza e densidade de vocalização de anuros (Amphibia) em uma área urbana de Corumbá, Mato Grosso do Sul, Brasil. Revista Brasileira de Zoologia, no. 21, p. 887-892.

BAKER, JM. and HALLIDAY, TR., 1999. Amphibian colonization of new ponds in an agricultural ladscape. Herpetological Journal, no. 9 , p. 55-63.

BELBIN, L., 1992. PATN: Pattern Analysis Package. Canberra, Austrália: Commonwealth Scientific Industrial Research Organization (CSI-RO).

BIAVATI, GM., WIEDERHECKER, HC. and COLLI, G., 2004. Diet of Epipedobates flavopictus (Anura: Dendrobatidae) in a Neotropical Savanna. Journal of Herpetology, no. 38, p. 510-518. http://dx.doi.org/10.1670/30-04A

BORROR, DJ. and DELONG, DM., 1988. Introdução ao Estudo dos Insetos. São Paulo: Editora Edgard Blucher.

CALDWEEL, JP. and VITT, LJ., 1999. Dietary asymmetry in leaf litter frogs and lizards in a transitional northern Amazonian rain forest. Oikos, no. 84, p. 383-397.

CONNEL, JH., 1980. Diversity and coevolution of competitors, or the ghost of competition past. Oikos, no. 35, p. 131-138.

CORREAA, MM., FERNANDES, WD. and LEAL, IR., 2006. Diversidade de formigas epigéicas (Hymenoptera: Formicidae) em capões do Pantanal Sul Matogrossense: relações entre diversidade e complexidade estrutural da área. Neotropical Entomology, no. 35, p. 724-730. http://dx.doi.org/10.1590/S1519-566X2006000600002

CUNHA, AA. and VIEIRA, MV., 2004. Two bodies cannot occupy the same place at the same time, or the importance of space in the ecological niche. Bulletin of the Ecological Society of America, no. 85, p. 25-26.

DAMASCENO, RP., 2005. Uso de recursos alimentares $e$ eletividade na dieta de uma assembléia de anuros terrícolas das dunas do médio Rio São Francisco, Bahia. São Pauo: Instituto de Biociências da Universidade de São Paulo. Master thesis.

DUELLMAN, WE. and TRUEB, L., 1994. Biology of Amphibians. London: Baltimore and London: McGraw-Hill.

ELPHICK, CS., 2004. Assessing conservation trade-offs: identifying the effects of flooding rice fields for waterbirds on non-target species. Biological Conservation, no. 117, p. 105-110. http://dx.doi.org/10.1016/S0006-3207(03)00264-7

FERREIRA, E., BARRIGOSSI, JAF. and VIEIRA, NRA., 2001. Percevejo das panículas do arroz: fauna heteroptera associada ao arroz. Emprapa Arroz e Feijão - Circular Técnica, no. 43, p. 25-53.

FLOWERS, MA. and GRAVES, BM., 1995. Prey selectivity and size-specific diet changes in Bufo cognatus and Bufo woodhousii during early postmetamorphic ontogeny. Journal of Herpetology, no. 29 , p. $606-612$

FRANÇA, L., FACURE, KG. and GIARETTA, AA., 2004. Trophic and spatial niches of two large-sized species of Leptodactylus (Anura) in Southeastern Brazil. Studies on Neotropical Fauna and Environment, vol. 39, p. 243-248. http://dx.doi. org/10.1080/01650520400007330

FUJIOKA, M. and LANE, SJ., 1997. The impact of changing irrigation practices in rice fields on frog population of the Kanto 
Plain, central Japan. Ecological Research, no. 12, p. 101-108. http://dx.doi.org/10.1007/BF02523615

GOTELLI, NJ. and ENTSMINGER, GL., 2001. EcoSim: Null models software for ecology. Version 7.0. Acquired Intelligence Inc. and KeseyBear. Available from: <http://homepages.together. net/ gentsmin/ecosim.htm>.

HADDAD, CFB. and PRADO, CPA., 2005. Reproductive modes in frogs and their unexpected diversity in the Atlantic Forest of Brazil. Bioscience, no. 55, p. 207-217.

HIRAI, T. and MATSUI, M., 2001. Foods hábitats of an endangered Japanese frog, Rana porosa brevipoda. Ecological Research, no. 16, p. 737-743. http://dx.doi.org/10.1046/j.1440-1703.2001.00430.x

HUTCHINSON, GE., 1961. The paradoxo of the plankton. Americal Naturalist, no. 95, p. 137-145.

ISACCH, JP. and BARG, M., 2002. Are bufonid toads specialized ant-feeders? A case test from Argentinian flooding pampa. Journal of Natural History, no. 36, p. 2005-2012. http://dx.doi. org/10.1080/00222930110092153

KNUTSON, MG., RICHARDSON, WB., REINEKE, DM., GRAY, BR., PARMELEE, JR. and WEICK, SE., 2004. Agricultural ponds support amphibian populations. Ecological Applications, no. 14, p. 669-684. http://dx.doi.org/10.1890/02-5305

LAWLOR, LR., 1980. Structure and stability in natural and randomly constructed competitive communities. Americal Naturalist, no. 112, p. 445-447.

LIMA, AP., 1998. The effects of size in the diets of six sympatric species of postmetamorphic litter anurans in Central Amazônia. Journal of Herpetology, no. 32, p. 392-399.

LIMA, AP. and MAGNUSSON, WE., 1998. Partitioning seasonal time: interactions among size, foraging activity and diet in leaflitter frogs. Oecologia, no. 116, p. 259-266.

MAEDA, T., 2001. Patterns of birds abundance and habitat use in rice fields of the Kanto Plain, central Japan. Ecological Research, no. 16, p. 569-585. http://dx.doi.org/10.1046/j.14401703.2001.00418.x

MAHAN, RD. and JOHNSON, JR., 2007. Diet of the gray treefrog (Hyla versicolor) in relation to foraging site location. Journal of Herpetology, no. 41, p. 16-23. http://dx.doi.org/10.1670/00221511(2007)41[16:DOTGTH]2.0.CO;2

Mato Grosso do Sul. 1989. Macrozoneamento Geoambiental do Estado de Mato Grosso do Sul. Campo Grande: Secretaria de Planejamento e Obras de Mato Grosso do Sul - SEPLAN. 242 p.

PIANKA, ER., 1973. The structure of lizard communities. Annual Review of Ecology and Systematics, no. 4, p. 53-74.

PIATTI, L., SOUZA, FL. and FILHO, PL., 2010. Anuran assemblage in a rice field agroecosystem in the Pantanal of central Brazil. Journal of Natural History, no. 44, p. 1215-1224. http:// dx.doi.org/10.1080/00222930903499804

PIHA, H., 2006. Impacts of agriculture on amphibians at multiple scales. Finland: University of Helsinki, Faculty of Bioscience. Doctoral dissertation.

PINKAS, I., OLIPHANT, MS. and IVERSON, ZL., 1971. Foods hábitats of albacore bluefin, tuna and bonito in California waters. California Department of Fish and Game Bulletin, no. 152, p. 1-350.

Plano de Conservação da Bacia do Alto Paraguai - PCBAP. 1997. Diagnóstico dos meios físico e biótico. Projeto Pantanal, Programa
Nacional do Meio Ambiente. Plano de Conservação da Bacia do Alto Paraguai. Meio físico, vol. II, Tomo I. Brasília: Ministério do Meio Ambiente.

PONSSA, ML., 2008. Cladistic analysis and osteological descriptions of the frog species in the Leptodactylus fuscus species group (Anura, Leptodactylidae). Journal of Zoological Systematics and Evolutionary Research, no. 46, p. 249-266.

PRADO, CPA., UETANABARO, M. and HADDAD, CFB., 2005. Breeding activity patterns, reproductive modes, and habitat use by anurans (Amphibia) in seasonnal environment in the Pantanal, Brazil. Amphibia-Reptilia, no. 26, p. 211-221.

PONCE, VM. and NUNES DA CUNHA, C., 1993. Vegetated earthmounds in tropical savannas of Central Brazil: a synthesis with special reference to the Pantanal at Mato Grosso. Journal of Biogeography, no. 20, p. 219-225.

RICHTER-BOIX, A., LLORENTE, GA., MONTORI, A. and GARCIA, J., 2008. Tadpole diet selection with the ecological context in predictable ways. Basic and Applied Ecology, no. 8, p. $467-474$

ROCHA, CFD., ARIANI, CV. and VRCIBRADIC D., 2008. Effects of a fire on population of treefrogs (Scinax cf. alter, Lutz) in a restinga habitat in southern Brazil. Brazilian Journal of Biology, no. 68, p. 539-543.

ROSA, I., CANAVERO, A., MANEYRO, R., NAYA, DE. and CAMARGO, A., 2002. Diet of four sympatric anuran species in a temperate environmet. Boletin de la Sociedad Zoologica del Uruguay, no. 13, p. 12-20.

RODRIGUES, DJ., UETANABARO, M. and PRADO, CPA., 2004. Seasonal and ontogenetic variation in diet composition of Leptodactylus podicipinus (Anura, Leptodactylidae) in the southern Pantanal, Brazil. Revista Espanola de Herpetologia, no. 18 , p. $19-28$.

SALE, PF., 1974. Overlap in resource use, and interspecific competition. Oecologia, no. 17, p. 245-256.

SANTOS, EM., ALMEIDA, AV. and VASCONCELOS, SD., 2004. Feeding habits of six anuran (Amphibia: Anura) species in a rainforest fragment in Northeastern Brazil. Iheringia Série Zoologia, no. 94, p. 433-438.

SANTOS, JC., COLOMA, LA. and CANNATELLA, DC., 2003. Multiple, recurring origins of aposematism and diet specialization in poison frogs. Proceedings of the National Academic Sciences, no. 100 , p. $12792-12797$.

SCHAEFER, EF., HAMANN, MI., KEHR, AI., GONZÁLEZ, CE. and DURÉ, M., 2006. Trophic, reproductive and parasitological aspects of the ecology of Leptodactylus chaquensis (anura: Leptodactylidae) in Argentina. Herpetological Journal, no. 16, p. $387-394$

SIMON, M. and TOFT, CA., 1991. Diet specialization in small vertebrate: mite-eating in frogs. Oikos, no. 61, p. 263-278. http:// dx.doi.org/10.2307/3545344

STRÜSSMANN, C., VALE, MBR., MENEGHINI, MN. and MAGNUSSON, WE., 1984. Diet and foraging mode of Bufo marinus and Leptodactylus ocellatus. Journal of Herpetology, no. 18 , p. $38-146$.

STRÜSSMANN, C., RIBEIRO, RAK., FERREIRA, VL., BÉDA, AF., 2007. Herpetofauna do Pantanal brasileiro. In Sociedade Brasileira de Herpetologia (Eds). Herpetologia no Brasil II. Belo Horizonte: Sociedade Brasileira de Herpetologia. p. 66-84. 
TOFT, CA., 1981. Feeding ecology of thirteen syntopic species of anurans in a seasonal tropical environment. Oecologia, no. 45, p.131-144.

UETANABARO, M., PRADO, CPA., RODRIGUES, DJ., GORDO,

M. and CAMPOS, Z., 2008. Guia de campo dos anuros do Pantanal e planaltos de entorno. Campo Grande: Editora UFMS.
VARGAS, AB., MAYHÉ-NUNES, AJ., QUEIROZ, JM., SOUZA, GO. and RAMOS, EF., 2007. Efeitos de fatores ambientais sobre a mirmecofauna em comunidade de restinga no Rio de Janeiro, RJ. Neotropical Entomology, no. 36, p. 28-37.

ZAR, JH., 1999. Biostatistical analysis. Upper Saddle River, New Jersey: Prentice Hall. 
